\title{
Teaching in Cross-Culture: A Worldwide Concern to Improve the Science Education in a Multicultural Perspective
}

\author{
Rafael Santos de Aquino \\ Federal Institute of Sertão \\ Pernambucano - IF \\ SERTÃO-PE
}

\author{
Ana M. A. Carneiro-Leão \\ Federal Rural University of \\ Pernambuco - UFRPE
}

Edenia M. Ribeiro Amaral

Federal Rural University of

Pernambuco - UFRPE

\begin{abstract}
The paper presents the results of a research in trend analysis on thematic focus of Teaching in CrossCultural and Crossing Cultural Borders in Science Teaching. Six journals were searched, three of them Brazilian and three internationals. All of them are free to access in the Internet and the research considered between the period of 2008 to 2018. Was used the word "culture" to search the articles and select considering the abstract to make sure that was about Cross-culture Teaching. The results show an increase in the number of publications in the area with a diversity of applications regarding levels of education as Elementary and Secondary School, undergraduate and graduate levels; different cultures or peoples as aborigines, immigrants, Afro-Americans, LatinAmericans, traditional peoples as fishermans and small farmers; in the formation of science concepts; teachers training; students' motivation; and cultural epistemological identification. In Brazil the researches in the area are under a STS approach and apply the theories indirectly. The countries with the highest production are Canada, USA, Australia and New Zealand with studies applied to indigenous peoples. In Europe the studies in the area are focused on immigrant multiculturalism. Asia researching its traditional ethnicities in Taiwan; and South America represented by Brazil with researches directed to farmers in the state of Bahia. The results suggest the need for more research in this area in Brazil, which presents great cultural diversity.
\end{abstract}

\section{Introduction}

Globalization is one of the main factors used to justify research and development in multicultural education, specifically in cross-cultural teaching due to the approach of different cultures [5], [7], [12], but when it comes to historically colonized countries like Brazil, where its original peoples and other enslaved peoples, seeks in multicultural education the institution of social justice to marginalized ethnic groups through the historical process.

In Brazil, there is a great cultural diversity, from the different ethnic groups indigenous to the AfroBrazilians, as well as the culture of the diverse
European peoples that settled here and brought with them the Western scientific culture.

This diversity of peoples in the social formation of the country gave rise to a naturally syncretic Brazilian people, but in the name of the hegemony of Eurocentric culture the traditional cultures of Indians, Afro-Brazilians and miscegenation transformed and formed our most diverse cultural expressions that remain marginalized [9].

Therefore, it is necessary for educators to look for the promotion of an education in cross-culture to meet the historical longings of these traditional peoples around the world.

Aikenhead contributed to the theory of crossing cultural frontiers that proposes the valorization of the indigenous culture of the students so that scientific enculturation takes place. Cobern contributes with works focused on the social importance of promoting educational inclusion to the North American Indians and the teacher training sensitive to this theme.

In order to understand the progress of this educational area in Science Teaching, it is necessary to ascertain how the research and scientific work in this area is going.

Through a bibliographic research in the area of cross-culture teaching and crossing of cultural boundaries in national and international journals aims to know the nature of research regarding its application, how theories was used and what the concepts of this area, the identification of authors and institutions, educational levels that are objects of study, diversity of peoples and cultures studied, as well as knowing the number of publications in the area by publications and how publications are distributed over at least a decade in the journals and throughout the history of editions of traditional events in the area.

This work was developed during the course of "Analysis of Trends in Research in Science Teaching and Textual Production" in the doctorate degree PostGraduate Program in Science and Mathematics Education, in Federal Rural University of Pernambuco (UFRPE), Brazil. Our objective was to analyze national and international trends of research related to the thematic focus cross cultural approaches in science education. This work is important to 
understand the current research tendencies on these themes in order to better define the subject for thesis situated among other researches in this area.

\section{Cross-Cultural Education}

Culture can be defined anthropologically as the norms, values, beliefs, expectations and conventional actions of a group [16], but due to the great complexity that permeates culture in its plurality other definitions are conferred on it as the material, social, cognitive aspects and cultural linguistic aspects as well as the ecological and social aspects.

Multicultural Education is increasingly valued and advocated by a number of educators and researchers, including Glen S. Aikenhead [2] who sought to investigate the dichotomy between indigenous knowledge and Western science. In addition, there are defenses for traditional knowledge to be recognized and included in scientific curricula in various contexts [11].

Culture and education confront each other when education becomes the vector of a hegemonic culture or a tool of colonialism, and this is exactly what stimulates the proposal for cross-culture education.

Cross-culture education takes place through the relationship between student subcultures and scientific subculture so that both cultural views are respected and related without overlap by any kind of social power. This concern in developing and researching cross-culture education has been increasing, especially in the developing countries of Latin America, Africa and Asia [4], [6], [10].

And it is also strong in developed countries that shared a colonization history seeking to perfect the process of inclusion of the peoples originating from their territories such as the Canadian and American Amerindians and the Australian and New Zealand Aborigines through education [7]. Consideration of the cultures of the peoples subjugated in the colonization process and living in the peripheral process currently guiding several works aimed at this decolonial current.

In this context, some theories and concepts have been proposed as the culturally relevant pedagogy of Ladson-Billings [8], which proposes a work plan for the empowerment of unconventional students and changes in the educational system; Pewewardy's culturally responsive model [15] which advocates the integration of multicultural content and the development of instructions aligned with the cultural learnings styles of students; the culturally congruent instructions of Parsons et al. [14] understood as a bridge between different cultures in which social values, language and knowledge must be considered and understood; as well as the crossing of cultural boundaries proposed by Aikenhead [2], which contributes to understand the cognitive process between different cultures.

\section{Cross Cultural Borders}

Glen S. Aikenhead [1], [2], [3] when engaging in indigenous educational studies in Canada proposed the crossing of cultural frontiers in science education that is based on social constructivist theories, based on the sociocognitive model of teaching and learning of O'Loughling [13] which exposes social power and its privileges in the classroom.

Aikenhead [2] conceived the term crossing cultural boundaries to describe how students move intellectually between the world of their daily lives and the world of school science and how they cognitively deal with the contextual differences between these two worlds. Border crossing are mediated by one of two processes: (1) enculturation, when the individual's worldview agrees with scientific culture, or (2) assimilation, when the student's worldview is at odds with scientific culture.

Border crossings are mediated by one of two processes: enculturation, when the world view of the individual agrees with scientific culture, or assimilation, when the student's worldview disagrees with scientific culture. Crossing cultural boundaries is considered by Grimberg and Gummer [7] as a constructivist theory situated in Multicultural Education.

Scientific education from a cultural perspective is based on several hypotheses [1]: (1) Occidental science is a culture of self-identity formed by several other subcultures of Euro-American societies; (2) people live and coexist identified in various subcultures characterized by languages, ethnicity, gender, social class, occupation, religion and geographic location; (3) people move from one subculture to another, a process called a "cultural border crossing"; (4) the major cultural identities of people may be at odds with the culture of Western science to varying degrees; (5) science classes are a subculture of school culture; (6) many students experience cultural change as they move from their own way of life to the world of school science; (7) so scientific learning is a cultural crossing; (8) students are more successful if they receive help when negotiating this crossing; (9) this help can come from the teacher who identifies the cultural boundaries to be crossed, leaving them out of cultural conflicts, motivating them to take advantage of the impact of Western science and technology in the students worldview.

They also advocate the construction of "mind bridges" to enable the inclusion of indigenous knowledge in the curriculum [1], [3], [10]. Gondwe and Longnecker [6] interpret the metaphor of Aikenhead's "mind bridge construction" stating that he put indigenous place knowledge and Western science in two different places and proposes to use a common ground between these two knowledges. Where should be the role of educators to pay attention 
to this common ground to act in the crossing of the students when they perceive the differences, breaking the visions and rebuilding the science and the relations with the indigenous knowledge.

Thus, reaching knowledge involves students in their own cultural negotiations between various sciences found within school science. With each cultural group there are subgroups most commonly identified by race, language, ethnicity, but which can also be defined by gender, social class, occupation, religion, etc. that constitute a subcultural group [2].

Studying the performance of high school students in the city of Ouricuri-PE, Brazil, specifically in the Chemistry discipline, Silva pointed there were statistically significant differences in student's performance among types of schools (public and private schools) and also between urban and rural schools and attributed among several identified factors family action, social condition and lack of contextualization of practical classes in rural areas [18], Silva pointed out that the various verified subcultural groups or aspects influenced the students' performance.

As a way of trying to explain the transition from one world to another or simply the crossing of cultural boundaries [16] proposed the student's multiple worlds model by helping to explain how students move from one world to another and four transitional categories: 1) congruent worlds support smooth transitions; 2) different worlds require transitions to be managed; 3) diverse worlds lead to dangerous transitions; and 4) highly discordant worlds make students resist transitions that are virtually impossible.

Aikenhead [2] argued that scientific content traditionally learned at school can rarely be applied to the everyday world, impeding the goal of building a skilled workforce for the development of a nation, and this is due to the foreign nature of scientific content. The low levels of education and consequent high rates of social vulnerability of ethnic minorities are the result of processes of historical and educational colonization that have suppressed or banned their knowledge systems, especially language and culture.

Considering that culture is variable, and the product of a given society constituted by language, habits and beliefs shaped by the historical and environmental effect.

When dealing with discourse analysis and pointing it as a tool applied to Education, which discourse is one of the aspects of ideological materiality that makes sense to a subject when he recognizes himself as belonging to a particular discursive formations present in a society are the result of the various ideological formations of a givens and determined epoch and society.

\footnotetext{
${ }^{1}$ Qualis Capes is a Brazilian evaluation system of Scientifics journals and Scientifics events and
}

The crossing of cultural boundaries requires contextualization that requires cultural immersion on the part of the teacher in the everyday world of the students, avoiding a colonizing teaching from a foreign point of view.

\section{Methodology}

Six journals (three Brazilian journals: Revista Investigações em Ensino de Ciências, Educação \& Sociedade e Revista Brasileira de Educação) and three internationals (Science Education, Journal of Research in Science Education e Journal of Research in Science Teaching) were investigated.

In addition to the journals, three events in the area were researched, two of them being national (National Meeting of Reserch in Science Education - Encontro Nacional de Pesquisa em Educação em Ciências ENPEC; National Meeting of of Teaching of Biology - Encontro Nacional de Ensino de Biologia ENEBIO) and one international (The International Congress of Research in Didactics of Sciences and of Mathematic - Congreso Internacional sobre Investigación en la Didáctica de las Ciências y de las Matemáticas too called in Spanish of Enseñanza de las Ciências).

The following data were computed and analyzed: identification of the country of origin of the research, the institution of the authors, the methodological nature, the research line under thematic focus and year. For the national production the same parameters were identified.

It was used for data tabulation, percentage calculations and graphs, Microsoft Excel ${ }^{\circledR}$ spreadsheets. For the journals that do not have free access such as the Journal of Research in Science Education and the Journal of Research in Science Teaching the articles selected for consultation were obtained through the Federated Academic Community (CAFe) service, which is a Brazilian governmental program for access to scientific information.

The selection of the journals occurred at random from the search for $\mathrm{A} 1{ }^{1}$ qualification according to the quadrennium 2013-2016 listed on the CAPES (Brazilian Coordination of Higher Education and Personnel) - Sucupira Platform site $<$ http://qualis.capes.gov.br/ $>$ for the Teaching evaluation area. The Qualis CAPES is a type of classification of journals and scientific events in Brazil where A1 is the best classification concept.

In the collection of journals, the search was given volume by volume from the year 2008 to 2018. In each volume was used the "Search" function of the Internet browser (Google Chrome), the word "Culture" was used in Portuguese and in English in

congresses that rank from A1, A2, B1, B2, B3, B4 and $\mathrm{C}$ (decreasing ranking). 
the international journals, being considered the title, the keywords and the summary in the initial process of surveying the articles. When identified, the references to identity relevant authors were searched to the theme as Glen S. Aikenhead and William W. Cobern. It was also considered the methodology to identify the research line, the methodological nature and the geographical origin of the work as a way of clarifying or identifying what was not exposed in the abstract of the articles.

The abstract was read to identify the thematic focus, and verification of the references to attest the presence of relevant authors to the topic. Also considered was the methodological nature and the geographic origin of the work.

The selection of the events was made according to the author's experience in participating in the main events in the area, since Capes no longer qualifies the events since 2009, but only classifies the journals and books. Because the selected events have a non-annual periodicity, the aim was to investigate them from the first edition to the last edition, thus ENPEC started in 1997, ENEBIO began in 2005 and the International Congress on Research of Sciences and Mathematics had its first edition in 1985.

The electronic addresses used in the survey are shown in Table 1. All sites were accessed from October $27^{\text {th }}$ through December $11^{\text {th }}, 2018$ through the Google.com search portal.

Table 1: Journals and events searched and their respective websites

\begin{tabular}{|c|c|c|}
\hline N. & Journals & Electronic Addresses \\
\hline 1 & $\begin{array}{c}\text { Revista } \\
\text { Brasileira de } \\
\text { Educação } \\
(R B E)\end{array}$ & $\begin{array}{l}\text { http://www.anped.org.br/ } \\
\text { news/rbe-revista- } \\
\text { brasileira-de-educacao-v- } \\
\text { 22-n-68-jan-mar- } 2017\end{array}$ \\
\hline 2 & $\begin{array}{l}\text { Educação \& } \\
\text { Sociedade } \\
\text { (E\&S) }\end{array}$ & $\begin{array}{l}\text { https://www.cedes.unica } \\
\text { mp.br/publicacoes/20 }\end{array}$ \\
\hline 3 & $\begin{array}{c}\text { Revista } \\
\text { Investigações } \\
\text { em Ensino de } \\
\text { Ciências (RIEC) }\end{array}$ & $\begin{array}{l}\text { https://www.if.ufrgs.br/cr } \\
\text { ef/ojs/index.php/ienci/ind } \\
\text { ex }\end{array}$ \\
\hline 4 & $\begin{array}{l}\text { Journal of } \\
\text { Research in } \\
\text { Science } \\
\text { Teaching } \\
\text { (JRST) }\end{array}$ & $\begin{array}{l}\text { https://onlinelibrary.wile } \\
\text { y.com/journal/10982736 }\end{array}$ \\
\hline 5 & $\begin{array}{l}\text { Journal of } \\
\text { Research in } \\
\text { Science } \\
\text { Education } \\
\text { (JRSE) }\end{array}$ & $\begin{array}{l}\text { https://link.springer.com/ } \\
\text { journal/11165 }\end{array}$ \\
\hline 6 & $\begin{array}{l}\text { Science \& } \\
\text { Education } \\
\text { (S\&E) }\end{array}$ & $\begin{array}{l}\text { https://onlinelibrary.wile } \\
\text { y.com/journal/1098237x }\end{array}$ \\
\hline
\end{tabular}

\begin{tabular}{|c|c|c|}
\hline 7 & ENPEC & $\begin{array}{l}\text { http://abrapecnet.org.br/ } \\
\text { wordpress/pt/atas-dos- } \\
\text { enpecs/ }\end{array}$ \\
\hline 8 & ENEBIO & $\begin{array}{l}\text { https://sbenbio.org.br/cat } \\
\text { egoria/anais/ }\end{array}$ \\
\hline \multirow[b]{2}{*}{9} & $\begin{array}{c}\text { Congreso } \\
\text { Internacional } \\
\text { sobre }\end{array}$ & $\begin{array}{l}\text { https://ensciencias.uab.es } \\
\text { /pages/view/congresos }\end{array}$ \\
\hline & $\begin{array}{l}\text { investigación } \\
\text { em la didáctica } \\
\text { de las Ciencias } \\
\text { y la Matemática }\end{array}$ & $\begin{array}{l}\text { https://www.raco.cat/ind } \\
\text { ex.php/Ensenanza/article } \\
\text { /view/21999 }\end{array}$ \\
\hline
\end{tabular}

\section{Results and Discussion}

\subsection{Periodic Quantitative Analysis}

A total of 3,501 articles were compiled from 2008 to 2018 in the six journals surveyed, nothing that the journals did not complete the publication of annual volumes for the year 2018. The magazine with the highest number of articles published among the six is Science \& Education with 951 articles followed by Journal of Research in Science Teaching with 614 articles for the period and third in number of published articles is the Educação \& Sociedade with 599 papers followed by the Journal of Research Science Education with 556, the Revista Brasileira de Educação with 452 and the Revista de Investigações em Ensino de Ciências with 329 articles (Table 2).

Table 2: Data from journal publications for the period 2008 to 2018.

\begin{tabular}{|c|c|c|c|}
\hline N. & Journals & $\begin{array}{c}\text { Total } \\
\text { Articles } \\
\end{array}$ & $\begin{array}{l}\text { Articles } \\
\text { in Area }\end{array}$ \\
\hline 1 & $\begin{array}{c}\text { Revista Brasileira de } \\
\text { Educação }(R B E)\end{array}$ & 452 & 0 \\
\hline 2 & $\begin{array}{c}\text { Educação \& } \\
\text { Sociedade }(E \& S)\end{array}$ & 599 & 0 \\
\hline 3 & $\begin{array}{c}\text { Revista Investigações } \\
\text { em Ensino de } \\
\text { Ciências (RIEC) } \\
\end{array}$ & 329 & 1 \\
\hline 4 & $\begin{array}{c}\text { Journal of Research in } \\
\text { Science Teaching } \\
\text { (JRST) }\end{array}$ & 614 & 11 \\
\hline 5 & $\begin{array}{c}\text { Journal of Research in } \\
\text { Science Education } \\
\text { (JRSE) }\end{array}$ & 556 & 4 \\
\hline 6 & $\begin{array}{c}\text { Science \& Education } \\
(\mathrm{S} \& \mathrm{E})\end{array}$ & 951 & 1 \\
\hline & TOTAL & 3501 & 17 \\
\hline
\end{tabular}

The journal JRST presented 11 articles in the area of Cross-Cultural Education, which is equivalent to the frequency of one article per volume, constituting itself as the magazine that published the most articles 
in the area, followed by JSRE with 4 articles in the area, but it is important to emphasize that the volume 50 of the journal, published in the year 2013, was a special edition on Multicultural Education, concentrating the publications on the theme.

Brazilian journals presented only 1 article with this thematic focus at RIEC, while foreign journals presented 16, but the disparity between the Brazilian and foreign journals investigated is revealed in the number of publications when we verified the percentage of editions (Brazilian 30.39\% and foreign $69.61 \%$ ) and published articles (Brazilian 39.42\% and foreign $60.58 \%$ ).

The publications in the area of thematic focus, object of our research presented higher production in the period from 2011 to 2013, when it had increasing annual frequency. In 2008, 2010, 2016 and 2017, there was no publication of articles addressing the teaching in cross-culture. It is possible to verify, in figure 1 , the trajectory of the trend line for the production in the area from 2008 to 2018 and its projection until 2021.

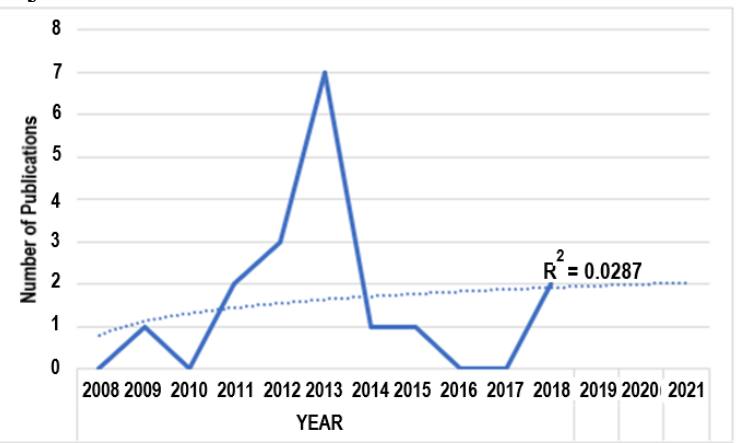

Figure 1. Number of publications about teaching in crossculture to period from 2008 to 2018 and logarithmic regression analysis projected to 2021

The analysis of this graph is important because it lows the visualization of productions in the thematic focus in a temporal way and interpret their numerical tendency estimated by the logarithmic regression analysis presented by the dotted line that projects line that projects the growth of publications in this thematic focus for three more periods $(2019,2020$ and 2021). Logarithmic regression was chosen due to data variations over time as it is the regressive analysis that best represents averages in data with high dispersion.

The coefficient of variation of this analysis is high evidenced by the low $R^{2}(0.0287)$ due to the unmanageable variables for the object of this study, which corresponds, for example, to the limitation of journals applied in this study, to the research behavior and publications of the researchers, to the economic and social conditions that influence the publications in higher impact magazines as in this case in Qualis A1, the low interest verified in Brazilian productions, among other factors. However, this analytical tool is interesting for interpreting the statistical trend in publications of this thematic focus.
The 17 articles found in the thematic focus area were analyzed according to authorship and identification of the country and institution to which the author and co-author belong. North America has the largest number of authors, 21 researchers that correspond to $46.70 \%$ of the universe of authors working in the thematic focus. Brazil represented only $4.44 \%$ of the authors and only one publication according to Table 3.

Table 3: Characterization and percentage analysis of the authors by geographic origin

\begin{tabular}{clcc}
\hline $\mathbf{N}^{\mathbf{0}}$ & Countries & Total & $\mathbf{\%}$ \\
\hline 1 & Switzerland & 3 & 6.67 \\
2 & Netherlands & 1 & 2.22 \\
3 & Greece & 2 & 4.44 \\
4 & Slovenia & 2 & 4.44 \\
5 & Turkey & 1 & 2.22 \\
\hline- & Europe & $\mathbf{1 0}$ & $\mathbf{2 2 . 2 0}$ \\
\hline 6 & Canada & 3 & 6.67 \\
7 & USA & 18 & 40.00 \\
\hline- & North America & $\mathbf{2 1}$ & $\mathbf{4 6 . 7 0}$ \\
\hline 8 & Brazil & 2 & 4.44 \\
9 & Colombia & 1 & 2.22 \\
\hline- & South America & $\mathbf{3}$ & $\mathbf{6 . 6 7}$ \\
\hline 10 & Taiwan & 3 & 6.67 \\
11 & Malaysia & 1 & 2.22 \\
\hline- & Asia & $\mathbf{4}$ & $\mathbf{8 . 8 9}$ \\
\hline 12 & Australia & 7 & 15.60 \\
13 & New Zealand & 1 & 2.22 \\
\hline- & Oceania & $\mathbf{7}$ & $\mathbf{1 5 . 6 0}$ \\
\hline- & TOTAL & $\mathbf{4 5}$ & $\mathbf{1 0 0 . 0 0}$ \\
\hline
\end{tabular}

From the universe of authors identified working the cross-cultural teaching theme focus we identified 20 men and 25 women corresponding to $44.44 \%$ and $55.55 \%$ respectively. Europe had the highest percentage of researchers with $30.00 \%$, while in North America women are the majority with $60.00 \%$ of researchers.

Continental America has the largest number of authors, 21 researchers corresponding to $46.70 \%$ of the universe of authors working in the thematic focus. This result is possibly because two of the biggest exponents of this theme Glen S Aikenhead and William W. Cobern are Canadian and US respectively. Brazil represented only $4.44 \%$ of the authors and only one publication.

The most prominent institutions in terms of frequency of representation in the scope of thematic focus articles in Europe are the University of Zurich, Switzerland with three representatives; University of Ljubljana in Slovenia and the University of Ioannina in Greece with two researchers each; in North America, the highlighted is the University of North Carolina with four representations, followed by North Dakota State University and University of South 
Florida with three representations each and Montana State University with two participations; in South America, the Feira de Santana State University in Bahia with two representations in cooperative of the Colombian Districtal University Francisco José Caldas; in Asia the four representatives belong to different institutions; and in Oceania stand out Murdoch University with four representatives and University of Western Australia with two.

\subsection{Qualitative Analysis}

For the qualitative analysis of production trends on Cross-Cultural Teaching, the information was categorized as to the identification of the article; the nature of practical work (application of theory in experimentation in the classroom for example) or theoretical (when the work deals with theoretical approaches in reviews, discussions and theoretical analysis); the direct application (when the Crossing Borders Culture Theory or Cross-Cultural Education is the object of the work being applied theoretically or practically) or indirect (when the use of the theory occurs in an indirect way not constituting itself as the main object of the research); the peoples studied (indigenous, Aboriginal Australians, African Americans, Latinos and immigrant students in the classrooms); the level of teaching in which the research was applied (Elementary School or High School); and the Research Application Area (formation of scientific concepts, teacher training, student motivation or school curriculum).

We identified six articles of theoretical nature and eleven of practical nature, nine of direct theoretical application and eight whose theory was secondary object, therefore, of indirect theoretical application. The theoretical works were represented by trend by trend analysis, critical analysis and theoretical deepening.

Practical works ranged from didactic application in the classroom, through motivational study of the study of science in multicultural classrooms to curricular analysis of science $t$ a certain level of education.

Among the traditional peoples, like Indians, Aborigines, Afro descendants that living and cultivate the own culture in other countries due the African diaspora, for example, we verified a study about the relation of cultural and scientific knowledge of farmers about the relation insect-plant in the outland of Bahia in Brazil [18]; five works that studied the indigenous theme in diverse regions of the world from North America with Mexico (Nahua people) and USA (Montana Indians) to Oceania (Taiwan - Amis people and New Zealand - Maori people) being the ethnic category with greater representativity of study with $38.46 \%$ [7], [10]; a study on scientific learning considering the culture of African-American and Hispanic Latin American residents; two studies on Australian Aborigines that accounted for 15.38\% [6] and three studies on cross-culture in the classroom made up of immigrants, performed in Switzerland and Greece computing 23.07\% [17].

Practical applications have demonstrated their performance in the Elementary and High School levels of several countries. In all, seven papers were applied in the elementary school series and four applied in high school and in six papers were not applied because they were theoretical. These data show that $63.63 \%$ of the work was applied in Elementary School and $36.36 \%$ applied in High School.

Of the theoretical approaches 55.55\% applied the Cultural Border Crossing, compared to $29.63 \%$ who used the principles of Multicultural Education. Use of these theoretical principles for the application of CTS represented $3.82 \%$ and $11.00 \%$ discussed decoloniality.

As to the area of application, it was observed that seven papers investigated the formation of scientific concepts, most belonging to the Biological Sciences representing 58.33\%; two studies (16.66\%) dealt with teacher training for multicultural education in crosscultural education; two studies $(16.66 \%)$ investigated the student's motivation phenomena for the study of cross-cultural science; and one that dealt with the scientific curriculum $(8.33 \%)$ for multicultural education and cross-cultural teaching.

\subsection{Event Quantitative Analysis}

The table 6 shows the editions of the events, as well as the number of articles published.

Table 4: Data from publications in each events since the first edition regarding total papers and thematic focus area

\begin{tabular}{|c|c|c|c|c|}
\hline $\mathbf{N}^{\mathbf{o}}$ & Events & Year & Papers & $\begin{array}{l}\text { Papers in } \\
\text { the Area }^{3}\end{array}$ \\
\hline 1 & I ENPEC & 1997 & 128 & 0 \\
\hline 2 & II ENPEC & 1999 & 163 & 0 \\
\hline 3 & III ENPEC & 2001 & 233 & 0 \\
\hline 4 & IV ENPEC & 2003 & 451 & 1 \\
\hline 5 & V ENPEC & 2005 & 824 & 1 \\
\hline 6 & VI ENPEC & 2007 & 601 & 0 \\
\hline 7 & VII ENPEC & 2009 & 799 & 1 \\
\hline 8 & VIII ENPEC & 2011 & 1235 & 4 \\
\hline 9 & IX ENPEC & 2013 & 1019 & 3 \\
\hline 10 & X ENPEC & 2015 & 1272 & 4 \\
\hline 11 & XI ENPEC & 2017 & 1335 & 12 \\
\hline \multicolumn{2}{|c|}{ TOTAL ENPEC } & - & 8060 & 26 \\
\hline 12 & I ENEBIO & 2005 & 283 & 0 \\
\hline 13 & II ENEBIO & 2007 & 219 & 0 \\
\hline 14 & III ENEBIO & 2010 & 419 & 0 \\
\hline 15 & IV ENEBIO & 2012 & 331 & 1 \\
\hline 16 & V ENEBIO & 2014 & 568 & 1 \\
\hline 17 & VI ENEBIO & 2016 & 699 & 4 \\
\hline
\end{tabular}




\begin{tabular}{|c|c|c|c|c|}
\hline 18 & VII ENEBIO $^{1}$ & 2018 & 528 & - \\
\hline \multicolumn{2}{|c|}{ TOTAL ENEBIO } & - & 3047 & 6 \\
\hline 19 & I CIIDCM & 1985 & 98 & 0 \\
\hline 20 & II CIIDCM & 1987 & 225 & 0 \\
\hline 21 & III CIIDCM & 1989 & 201 & 0 \\
\hline 22 & IV CIIDCM & 1993 & 174 & 0 \\
\hline 23 & $\mathrm{~V}$ CIIDCM $^{2}$ & 1997 & - & - \\
\hline 24 & VI CIIDCM & 2001 & 13 & 0 \\
\hline 25 & VII CIIDCM & 2005 & 539 & 0 \\
\hline 26 & VIII CIIDCM & 2009 & 724 & 2 \\
\hline 27 & IX CIIDCM & 2013 & 678 & 1 \\
\hline 28 & X CIIDCM & 2017 & 875 & 0 \\
\hline \multicolumn{2}{|c|}{ TOTAL CIIDCM } & - & 3527 & 4 \\
\hline \multicolumn{2}{|c|}{ TOTAL GENERAL } & - & 14634 & 35 \\
\hline
\end{tabular}

${ }^{1}$ The edition of ENEBIO 2018 has not yet publications available; ${ }^{2} \mathrm{~V}$ CIIDCM publications are not available on the Portal of Journal Enseñanza de las Ciencias; ${ }^{3}$ Articles published in the area of thematic focus.

The survey of productions in the three events chosen since the first edition of each of them shows that the first publications made in the area of crosscultural teaching thematic focus took place in 2001 at the III ENPEC. Among the events, ENPEC presented the largest publication of articles with 8,060 papers which representing 55.08\%, ENEBIO with 3,047 papers published $(20.81 \%)$ and CIIDCM with 3,527 papers $(24.11 \%)$. This frequency of publications places ENPEC as an important event in the area of Science Education, also favoring the diversity of publications in various branches of the area, in which, for the area of thematic focus, ENPEC presented 28 papers throughout its editions, representing $73.69 \%$ of the cross-cultural Science Teaching publications and ENEBIO with 6 publications (15.79\%) and CIIDCM with 4 publications in the field $(10.52 \%)$.

There is also an intensification of productions in the area of increasing thematic focus from 2001 where between 2000 and 2009 were $14 \%$ of publications against $86 \%$ of period from 2010 to 2017 .

Even though the decade of 2010 has not been completed, it is evident that the production in this thematic line represents more than $78 \%$ of the scientific production in these events for the period from 2011 to 2017. The considerations of the publications in the three events, for the period from 2001 to 2017, serve as a statistical indicate that scientific production in the area will continue to increase, as can be seen in figure 2, which shows the quantitative trend in publications of articles on thematic focus with a projection of four years beyond the period investigated (2018 to 2021).

The 32 articles identified in the three researched events were analyzed for authorship characteristics such as gender, institution and origin of the authors and co-authors.

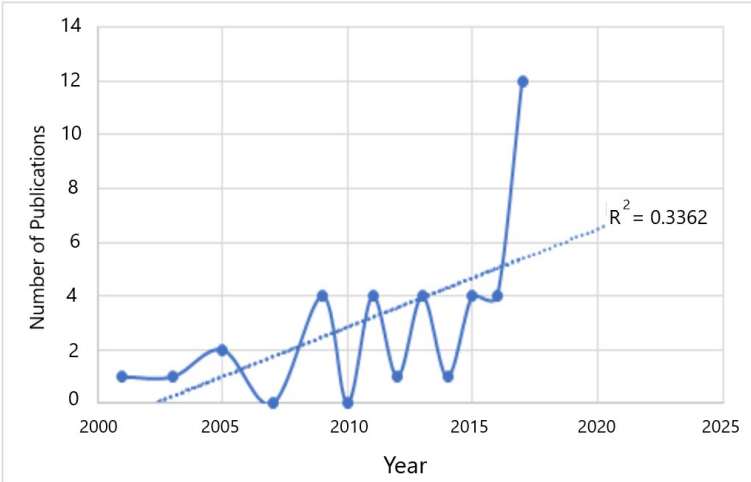

Figure 4: Number of publications on Cross-Culture Teaching and Multicultural Education in Science Education from 2001 to 2017 and projection of the productive trend for another four years (2018 to 2021)

Based on the data from the authors and institutions of all articles, we find that $66 \%$ of authors are women and $33.73 \%$ are men. Some names are repeated in different publications indicating that they militate in this area of research. The authors are linked to 19 different institutions, two of them foreign (Colombia and Spain), mostly higher education institutions acting in postgraduate programs where the only exceptions in the presence of a managing body, which is the Secretary of Education from Espírito Santo Brazilian State. Among the educational institutions the main municipalities are the Federal and State Public Universities followed by the Federal Institutes and Federal Technological Education Centers.

The institutions with the largest number of authors wee the Francisco José de Caldas District University (UDFJC) of Colombia, with $24.11 \%$ of the total cataloged authors, followed by the Federal Institute of Espírito Santo (IFES) with $16.87 \%$ of the authors, the Federal University of Bahia (UFBA) with $15.66 \%$ the Federal University of Minas Gerais (UFMG) with $8.44 \%$ of the authors, the State University of Maringá (UEM-PR) with $6.03 \%$ and the University of São Paulo (USP) and University of Triangulo Mineiro (UFTM) with $4.82 \%$ each were represented with $1.20 \%$ of the authors.

It was also possible to identify productivity by institution, where we computed the total number of articles for each institution. The higher representativeness of authors also ranks as the most productive, such as UDFJC, the Colombian institution accounted for $17.14 \%$ of all production being the only one with publications in the three researched events. In second place is UFBA with $14.28 \%$ of all production and IFES which accounts for $11.44 \%$ of published articles. Brazilian institutions have not published in the Congress of International Research in Didactics in Science and Mathematics (CIIDCM) regarding the thematic focus of this work. 
Brazilian production could be analyzed and quantified with the state of Bahia accounting for $28.13 \%$ of publication in the area, followed by Espírito Santo and Minas Gerais tied with $12.50 \%$ of production, third also tied are Rio de Janeiro and the state of Sao Paulo with $9.38 \%$ of publications in the area. Internationally Colombia accounts for $18.75 \%$ of publications.

\subsection{Event Qualitative Analysis}

When analyzing the 32 articles published in ENPEC, ENEBIO and CIIDCM, it was found that 24 of them were practical studies and only 8 theoretical ones. Regarding the application of the theory of Cross-Culture Teaching, Crossing Cultural Borders only one paper published in the VIII ENPEC in 2011 he applied the theory of Crossing Cultural Borders as the main theoretical element and work was developed in Colombia by the Francisco José de Caldas District University. And the remaining 31 works apply the theory indirectly.

The studies also bring interesting results regarding the worked cultures where we verified 5 studies (29.41\%) with indigenous and identified five indigenous ethnicities (Pataxó and Xakriabá between Minas Gerais and the south of Bahia; Guateka in Mato Grosso do Sul; and Tupi Guarani and Ywy Pyaú in São Paulo) two other works that did not identify the cultures, one that investigated indigenous science learning in São Paulo and the other with the formation of concepts in teacher education in Colombia with students from different traditional communities.

Another 5 articles (29.41\%) that investigated cultural issues with urban; $2(11.77 \%)$ with the religious subculture investigating the conflicts of evangelical Christian belief with evolutionary theory, $3(17.65 \%)$ about traditional fishermen and shellfish populations in Salvador-BA, and 1 (5.88\%) about immigrants and their ways of learning in a multicultural classroom and another about farmers $(5.88 \%)$ and the survey of their traditional knowledge about plant growth. Three of the indigenous works were found at ENPEC and two at ENEBIO, of which one was developed in Colombia. The only work on the cultural relations of immigrants was published in the VIII CIIDCM in 2009 on the Spanish context.

The levels of education identified in the applications of the studies were quite variable with 13 studies $(59.10 \%)$ in high school, 3 of them applied in the professional modality at the Federal Institute of Bahia (IFBA) and two at the Federal Institute of Espírito Santo (IFES), constituting as the level of education. Then the higher levels (being three works applied in undergraduate classes and one in bachelor's degree) and Elementary level with 4 works (18.18\%) each. A postgraduate application at the master level $(4.54 \%)$
As for the field of application 12 papers were concerned with investigating the formation of scientific concepts $(46.15 \%)$, followed by teacher education with 9 papers identified $(34.62 \%)$ and 5 papers on epistemological research to identify epistemologies $(19.23 \%)$ that generate resistance when relating to the scientific epistemologies of which two dealt with the religious epistemological relations.

\section{Conclusion}

International productions apply the Cultural Border Crossing Theory to investigate the teachinglearning process of indigenous people in several countries and continents and in a multicultural classroom composed of immigrant, a situation common to the US and European countries.

North America leads the production of research in this thematic focus with emphasis on the USA that mainly works in cognitive research of Amerindians and immigrants and Mexico that studied the crossing of borders in the education of the Nahua people; Europe is second in the area by researching immigrant multiculturalism in schools; Oceania researching the border crossing between Aboriginal students from New Zealand and Australia; Asia researching its traditional ethnicities in Taiwan; and South America represented by Brazil with researches directed to farmers in the state of Bahia.

The researches serve several areas of application, the main one being the formation of concepts, then the training of teachers and the investigation of epistemologies that influence the crossing of cultural boundaries. They contemplate the different levels of education, highlighting the Elementary and Secondary Education.

Research in Brazil adopt, in general, the concepts from cross-cultural teaching, such as proposed in the theory of Crossing cultural boarders of Aikenhead, but they are indirectly explored with a STS approach.

It is pertinent to expand the research including the important Brazilian journal in the research in science education area called Revista Brasileira de Pesquisa em Educação em Ciências with Qualis CAPES A2 for its direction in the area of science teaching, enhancing the results in Brazil.

Cross-Cultural research and the application of cross-border cultural theory should be stimulated and have a great deal of space for discoveries to understand how the cultural negotiations happen and the consequent process of learning of scientific knowledge by students of cultures in Brazil and in the world.

The production in this area have as main theorists Glen Aikenhead and William Cobern in the world and in South America scope stand out the Colombian researchers Adela Molin Andrade, Rosa Inés Pedreros Martínez, Lyda Mojica Rios and Carlos Javier 
Mosquera Suarez from the District University Francisco José de Caldas.

In Brazil, UFBA researchers Geilsa Costa dos Santos Baptista, Rosiléia Oliveira de Almeida and Charbel El-Hani; IFES researchers Vilma Reisi Terra and Sidnei Quesada Meireles and Danilo Seithi Kato from UFTM stand out.

Finally, the results suggest the need for more research in this area in Brazil mainly to explore the internationalization of research, which presents great cultural diversity.

\section{References}

[1] Aikenhead, G.S. (2001). Integrating Western and Aboriginal Sciences: cross-culture Science teaching. Research in Science Education, v. 31, nº. 3, pp. 337-355.

[2] Aikenhead, G.S. (1996). Sciene Education: border crossing into the subculture of Science. Studies in Science Education, v. 27, pp. 1-52.

[3] Aikenhead, G.S. (1997). Toward a first nations crosscultural sicence and technology curriculum. Culture and Comparative Studies, William W. Cobern, $2^{\text {a }}$ ed., pp. 217238

[4] Carlone, H. B., Haun-Frank, J., and Webb, A. (2011). Assessing equity beyond knowledge - and skills - based outcomes: a comparative ethnography of two Fourth-Grade reform-based Science Classrooms. Journal of Research Science Teaching, v. 48, $\mathrm{n}^{\circ} .5$, pp. 459-485.

[5] Eijck, M., and Roth, W. M. (2011). Cultural diversity in Science education through novelation: against the epicization of Science and cultural centralization. Journal of Research Science Teaching, v. 48, nº. 7, p. 824-847.

[6] Gondwe, M., and Longnecker, N. (2015). Scientific and cultural knowledge in the cultural Science education: student pereptions of common ground. Journal of Research Science Education, v. 45, pp. 117-147.

[7] Grimberg, B. I., and Gummer, E. (2013). Teaching Science from cultural points of intersection. Journal of Research Science Teaching, v. 50, n. 1, pp. 12-32.

[8] Ladson-Billings, G. (1995). Toward a theory of culturally relevant pedagogy. American Educational Research Journal, v. 32, pp. 465-491.

[9] Laraia, R.B. (2001) Cultura: um conceito antropológico. 14. ed., Rio de Janeiro: Jorge Zahar Ed.

[10] Lee, H., Yen, C.F., and Aikenhead, G. S. (2012). Indigenous elementary students' Science instruction in Taiwan: indigenous knowledge and western Science. Journal of Research Science Education, v. 42, pp. 11831199.

[11] Monteiro, E.P., Zuliani, S.R.Q.A., Mesquita, P.J., and Almeida, A.W.B. (2017). Estudos culturais para o ensino de ciências em uma perspectiva crítica e pós-colonial: o caso da etnociência. XI Encontro Nacional de Pesquisa em Ensino de Ciêncis-ENPEC, Florianópolis, SC, Brazil.

[12] Nadenka, B.M.B., and Andrade, A.M. (2015). Discussões sobre a transição entre escola, conhecimento científico e conhecimento ecológico tradicional: uma análise para salas de aula culturalmente diferenciadas. $X$ Encontro Nacional de Pesquisa em Ensino de CiênciasENPEC, Águas de Lindóia, SP, Brazil.

[13] O'Loughlin, M. (1992). Rethinking science education: Beyond Piagetian constructivism toward a sociocultural model of teaching and learning. Journal of Research in Science Teaching, v. 29, pp. 791-820.

[14] Parsons, E.C., Foster, S., Travis, C., Simpson, J.S. (2005). The Black Cultural Ethos, students' instructional context preferences, and student achievement: An examination of culturally congruent science instruction in the eighth grade classes of one African American and one Euro-American teacher. The Negro Educational Review, v. 56, pp. 183-204.

[15] Pewewardy, C. (1998). Our children can't wait: Recapturing the essence of Indigenous schools in the United States. Cultural Survival Quarterly, v. 22, pp. 29-34.

[16] Phelan, P., Davidson, A., and Cao, H. (1991) Students' multiple worlds: Negotiating the boundaries of family, peer, and school cultures. Anthropology and Education Quarterly, v. 22, pp. 224-250.

[17] Piliouras, P., and Evangelou, O. (2012) Teachers' inclusive strategies to accommodate 5th Grade pupils' crossing of cultural borders in two Greek multicultural sicence classrooms. Journal Research Science Education, v. 42, pp. 329-351.

[18] Silva, A.P.F. (2016) Desempenho comparativo de alunos em diferentes esferas do municipio de Ouricuri-PE: um desafio para a educação profissional. Trabalho de Conclusão de Curso em Licenciatura Plena em Química do Instituto Federal do Sertão Pernambucano Campus Ouricuri, Ouricuri-PE, pp. 54.

\section{Acknowledgement}

To FACEPE (Foundation of support to the science of the state of Pernambuco) for granting the scholarship and the Federal Institute of Sertão Pernambucano (Sertão Pernambucano is a semiarid and poor region in the outland of Pernambuco State, Brazil, but is prevalent in much of Northeast region) for the granting of a doctoral leave. 